\title{
UJI FISIK SEDIAAN GEL EKSTRAK TONGKOL JAGUNG (Zay Mays L)
}

\author{
Indri Kusuma Dewi, MeyRachmawati, Fathiya Abdinnisa' Ma'rifah, Puspita Susilowati \\ Kementerian Kesehatan Politeknik Kesehatan Surakarta Jurusan Jamu \\ Diterima : 10 Agustus 2018, Disetujui : 23 Agustus 2018
}

\begin{abstract}
Background : Corn cobs have the potential to protect the skin, so far the research has only been limited to testing the extracts and has not been formed in a cosmetic preparation. Gel is a cosmetic preparation that is ideal for sunscreens because it is less oily, not sticky, soft, elegant, can form a layer of film that adheres well and protects the skin, and evaporation of water content creates a soothing and pleasant effect. Method: The method is used to determine the physical appearance of the gel with organoleptic parameters, homogeneity, dispersion and absorbency. Result: The purpose of this study was to determine the results of the physical test of sunscreen gel preparations from corn cobs extract (Zea mays L). Conclusion: The physical test results from the sunscreen gel extract of corn cobs extract (Zay Mays L.) had the results of organoleptic test, homogeneity test, spreadability test and adherence to the standard.
\end{abstract}

Keyword: Physical Test, Sunscreen Gel, Corn Cob

\section{PENDAHULUAN}

Tongkol jagung merupakan simpanan makanan untuk pertumbuhan biji jagung selama melekat pada tongkol. Tongkol jagung juga bagian terbesar dari limbah jagung. Dari berat jagung bertongkol, diperkirakan $40-50 \%$ adalah tongkol jagung, yang besarnya dipengaruhi oleh varietas jagungnya. Oleh karena itu dapat diperkirakan untuk produksi jagung 13 juta ton (jagung pipilan) akan terjadi limbah tongkol jagung sekitar 10,6 juta ton/ tahun (Richana, et al., 2004). Berdasarkan hal tersebut perlu adanya perhatian dan penanganan untuk pemanfaatan limbah tongkol jagung sehingga dapat lebih bermanfaat. Selama ini limbah tongkol jagung hanya dibuang, atau hanya digunakan sebagai bahan bakar dapur dan pengasapan untuk mengusir nyamuk.

Pada tahun-tahun belakangan ini, terdapat beberapa senyawa bahan alam yang telah dimanfaatkan sebagai agen pelindung sinar UV. Selain itu, penelitian Svobodova et al. (2003) menunjukkan bahwa senyawa-senyawa fenolik dapat berperan sebagai bahan aktif tabir surya. Telah diteliti sebelumnya tentang jagung, oleh Hossain et al. (2006) dengan mengidentifikasi senyawa antioksidan flavonol glikosida dan kuersetin dari biji jagung, dan Mongan et al. (2011) mengenai antioksidan asap cair yang dibuat dari bahan dasar tongkol jagung.

Hal ini didukung oleh Panovska et al. (2005) yang mengungkapkan senyawa antioksidan merupakan suatu inhibitor yang digunakan untuk menghambat auto oksidasi. Selain itu Saleh et al. (2012) mengungkapkan bahwa senyawa aktif yang terkandung dalam ekstrak tongkol jagung memiliki kemampuan yang baik dalam menangkal radikal bebas yang bekerja menghambat oksidasi dengan cara bereaksi dengan radikal bebas reaktif membentuk radikal bebas tak reaktif yang relatif stabil sehingga memungkinkan 
bermanfaat dalam memperlambat proses fotooksidasi akibat paparan sinar UV matahari. Sinar matahari merupakan sumber energi yang berperan penting bagi kehidupan makhluk di bumi yang terbagi atas berbagai jenis, diantaranya dipermukaan bumi sinar matahari terdiri dari beberapa spektrum yaitu sinar infra merah (>760nm), sinar tampak (400-760 $\mathrm{nm})$, sinar ultra violet (UV) A (315-400 $\mathrm{nm})$, sinar UV-B (290-315 nm), dan sinar UVC (100-290 nm) (Kaur dan Saraf,2009) mengemukakan bahwa dalam jumlah kecil, radiasi UV-B bermanfaat untuk sintesis vitamin D dalam tubuh. Tetapi paparan sinar matahari yang melimpah dengan intensitas yang tinggi dapat menyebabkan hiperpigmentasi kulit sehingga kulit menjadi kusam dan bersisik bahkan dapat juga menyebabkan kerusakan fotokimia pada DNA sel sehingga memicu pertumbuhan kanker kulit. Menurut Satiadarma (1986), untuk mencegah efek buruk papanan sinar matahari dapat dilakukan dengan cara menggunakan tabir surya.

Gel merupakan pembawa yang ideal untuk tabir surya karena kurang berminyak, tidak lengket, lembut, elegan, dapat membentuk lapisan film yang melekat dengan baik dan melindungi kulit, serta penguapan kadar airnya menimbulkan efek yang menyejukkan dan menyenangkan. Oleh sebab itu, perlu dilakukan penelitian menguji fisik sediaan gel tabir surya dari limbah tongkol jagung.

\section{METODE PENELITIAN}

Penelitian ini menggunakan jenis penelitian diskriptif.Desain penelitian yang digunakan peneliti yaitu observasi atau pengamatan. Jenis observasi yang digunakan oleh peneliti yaitu observasi. Penelitian ini mengamati hasil fisik sediaan gel ekstrak tongkol jagung (Zea mays. L), Tongkol jagung manis segar 2 $\mathrm{kg}$ dari home industry di wilayah klaten dikeringkan dengan cara dikeringkan dalam oven pada suhu $40^{\circ} \mathrm{C}$ sampai menjadi simplisia kering dan diperoleh berat kering 700 g. Simplisia kering $700 \mathrm{~g}$ dihaluskan dan diayak, didapat berat serbuk sebesar 545 gram. Pembuatan ekstrak tongkol jagung dilakukan dengan metode maserasi, yaitu tongkol jagung dihaluskan, lalu diayak, ditimbang sebanyak $200 \mathrm{~g}$ lalu diekstraksi dengan menggunakan $2.000 \mathrm{ml}$ etanol 96\% dengan perbandingan 10 simplisia dengan 100 penyari. Maserasi dilakukan dengan cara merendam semua serbuk tongkol jagung sebanyak $200 \mathrm{~g}$ dengan penyarinya $1500 \mathrm{ml}$ selama 5 hari dengan pengadukan setiap 30 menit. Kemudian di saring dan dilakukan Remaseri dengan penambahan penyari pada sisa ampas Maserasi sebanyak 500ml, lalu dilakukan perendaman selama 2 hari. Kemudian sari dipanaskan sampai menjadi ekstak kental di water bath hingga memperoleh ekstrak. Di dapatkan ekstrak kental sebanyak 31,05 g. Gel ekstrak tongkol jagung terdiri dari zat aktif ekstrak tongkol jagung dan bahan tambahan.

Tabel 1. Komposisi formulasi gel ekstrak tongkol jagung (Zea mays L.)

\begin{tabular}{cc}
\hline Bahan & Formula (gram) \\
\hline Ekstrak TongkolJagung & 4,30 \\
CMC-Na & 1,56 \\
KOH & 0,02 \\
Asam Sitrat & 0,02 \\
Na Sitrat & 0,01 \\
Gliserin & 3,1 \\
Metil paraben & 0,07 \\
Aquadest ad & 177 \\
Parfume & q.s. \\
\hline
\end{tabular}




\section{HASIL PENELITIAN}

Hasil dari data pengujian yang telah dilakukan memperoleh hasil rendemen 200g tongkol jagung menggunakan pelarut etanol $96 \%$ sebanyak $2.000 \mathrm{~mL}$ adalah $15,525 \%$.

Uji Fisikdengan jenis gel ekstrak tongkol jagung, berbentuk semi solid, berwarna kuning muda, berbau khas jagung manis bertekstur lembut dengan sensasi dingin gel.

Berdasarkan hasil homogenitas dapat diketahui hasil uji homogenitas dari formula sediaan gel ekstrak tongkol jagung yaitu homogen.

Hasil uji $\mathrm{pH}$ sediaan gel ekstrak tongkoljagungdiketahui hasil uji $\mathrm{pH}$ dari formula sediaan gel ekstrak tongkol jagung memiliki pH 6.

Hasil uji daya sebar dari formula sediaan gel ekstrak tongkol jagung memiliki daya sebar sebesar $6,9 \mathrm{~cm}$.

Hasil uji daya lekat dari formula sediaan gel ekstrak tongkol jagung memiliki daya lekat sebesar 46 sekon.

\section{PEMBAHASAN}

Dalam ekstraksi menggunakan maserasi diperoleh randemen cukup banyak karena didalam tongkol jagung mengandung senyawa fenol mencakup sejumlah senyawa-senyawa yang umumnya mempunyai sebuah cincin aromatik dengan satu atau lebih gugus hidroksil (Geisman dan Crout, 1969). Cincin aromatik membuat senyawa ini berkurang kepolarannya sehingga sifat konsentrasi etanol yang tinggi lebih mampu melarutkan senyawa fenolik karena etanol selain bersifat polar juga memiliki gugus non polar yaitu $\mathrm{CH}_{3}-\mathrm{CH}_{2}-$ yang membuat senyawa fenolik lebih suka larut dalam pelarut etanol. Ekstrak kental yang dihasilkan digunakan sebagai bahan untuk membuat gel tabir surya. Kemudian di uji untuk mengetahui kualitas gel ekstrak tongkol jagung yang dihasilkan.

Berdasarkan hasilorganoleptis gel ekstrak tongkol jagung menghasilkan warna yang baik dan sesuai dengan bahan yang digunakan. Gel ekstrak tongkol jagung beraroma khas jagung manis. Lamanya waktu penyimpanan gel ekstrak tongkol jagung akan mempengaruhi aroma sehingga perlu adanya penambahan aroma. Aroma tersebut berasal dari minyak mawar, minyak kenanga, dan lavender yang alami dan aman digunakan, selain aroma dan warna, tekstur gel juga harus diperhatikan. Tekstur yang baik adalah lembut dan dingin ketika digunakan. Hal tersebut sesuaidengan hasil yang didapatkan yaitu lembut dan dingin saat digunakan.

Uji pH juga merupakan hal penting, karena apabila $\mathrm{pH}$ tidak sesuai kulit akan berbahaya jika gel digunakan untuk kulit.

Berdasarkan $\mathrm{pH}$ kulit alami pada rata-rata 4,7 dan sering dilaporkan bahwa $\mathrm{pH}$ kulit antara 5,0 dan 6,8. $\mathrm{pH}$ permukaan kulit tidak hanya bervariasi di lokasi yang berbeda, tetapi juga dapat mempengaruhi profil $\mathrm{pH}$ di stratum korneum (Ansari., dkk, 2009), oleh karena itu gel ekstrak tongkol jagung dengan $\mathrm{pH} 6$ ini dapat digunakan pada kulit dan aman karena sesuai $\mathrm{pH}$ kulit.

Hasil uji daya sebar dari formula sediaan gel ekstrak tongkol jagung memiliki daya sebar sebesar $6,9 \mathrm{~cm}$ sesuai dengan penelitian yang dilakukan Garge et al., 2002 dalam Mappa et al., 2013 bahwa daya sebar gel yang baik antara 5-7 $\mathrm{cm}$.

Berdasarkan uji daya lekat dari formula sediaan gel ekstrak tongkol jagung memiliki daya lekat cukup tinggi 
sebesar 46 sekon sesuai syarat daya lekat yang baik adalah lebih dari 1 detik (Jayadi, 2013). Pengujian yang dilakukan untuk mengetahui kekuatan gel pada kulit. Semakin lama salep melekat pada kulit maka efek yang di timbukan juga semakin besar.

\section{KESIMPULAN DAN SARAN}

Uji fisik dari sediaan gel tabir surya ekstrak tongkol jagung (Zay Mays L.) memiliki hasil uji organoleptik, uji homogenitas, uji daya sebar dan daya lekat yang sesuai standar

\section{DAFTAR RUJUKAN}

Kaur, C. D dan Saraf, S. 2009. In Vitro Sun Protection Faktor Determination of Herbal Oils Used in Cosmetics. Pharmacognosy Research. 2:22-23.

Richana, N., P. Lestina dan T.T. Irawadi. 2004. Karakterisasi lignoselulosa: xilan dari limbah tanaman pangan dan pemanfaatannya untuk pertumbuhan bakteri RXA III-5 penghasil xilanase. J. Penelitian Pertanian 23 (3): 171-176

Saleh, L.P., E. Suryanto., A. Yudistira. 2012. Aktivitas Antioksidan dari Ekstrak Tongkol Jagung (Zea mays L.). Pharmacon. 1 : 20-24.

Svobodova, A., J. Psotova., D. Walterova. 2003. Natural Phenolics in the Prevention of UV-Induced Skin Damage. Biomed. Pap. 147 : 137145. 